\title{
A Lucky Case: An Unusual Penetreting Injury of the Scrotum in an Adolescent: Traumatic Implantation of a Rebar
}

\author{
Şanslı Bir Vaka: Bir Adolesanda Skrotumun Nadir Görülen Delici Yaralanması: Travmatik Delici İnşaat Demiri
}

Ramazan Karabulut, Zafer Türkyılmaz, Kaan Sönmez, Aslı Ozbayoğlu, Yıldız Pehlivan, A. Can Başaklar

Gazi University Medical Faculty, Department of Pediatric Surgery, 06500, Besevler, Ankara, Turkey

\begin{abstract}
Penetrating scrotal trauma usually results with injury to immediate structures including testis, urethra, vas deferens and vessels or adjacent nongenital structures. In a limited number of published scrotal trauma cases in literature, associated organ trauma or injury to adjacent structures were usually present. In this case report, a patient with isolated scrotal penetrating injury due to a rebar is presented. To our knowledge, such a trauma with regard to its occurrence and limited damage is the first in the medical literature.
\end{abstract}

Key Words: Scrotum, penetrating trauma, rebar injury

Received: 07.12.2015

Accepted: 09.29.2015

\section{ÖZET}

Penetran skrotal travma genellikle hemen yanındaki testis, üretra, vas deferens ve damarlar veya komşu nongenital yapılar da dahil olmak üzere komşu yapıların yaralanması ile sonuçlanır. Literatürde yayınlanan sınırlı skrotal travma vakalarında organ travması ya komşu yapılarda yaralanma genellikle bulunur. Bu olgu sunumunda, inşaat demiri nedeniyle oluşan izole skrotal penetran yaralanmalı bir hasta sunulmuştur. Bildiğimiz kadarıyla, oluşum biçimi ve sınırlı hasarıyla böyle bir travma tıp literatüründe ilktir.

Anahtar Sözcükler: Skrotum, delici travma, inşaat demiri travması

Geliş Tarihi: 12.07.2015

Kabul Tarihi: 29.09.2015

\section{INTRODUCTION}

Scrotal trauma accounts for less than $1 \%$ of all trauma-related injuries in children, because of the anatomic location and mobility of the scrotum(1). Penetrating trauma involving the scrotum causes damage not only to testicular structures but also to adjacent structures and organs. Therefore, a systemic rather than a local approach should be considered for these patients. More exceedingly rare is a penetrating injury involving the scrotum solely, without causing any damage to its contents and nearby structures $(2,3)$. In this case report, a patient with an isolated scrotal penetrating injury due to a rebar (reinforcing steel) is presented. To our knowledge, such a trauma with regard to its occurrence and limited damage is the first in the medical literature.

\section{CASE REPORT}

A 15-year-old boy was brought to the pediatric emergency department with a rebar stuck in his scrotum. The patient had fallen on the rebar while taking pictures with his friends at an empty construction area and was impaled on it. Firemen cut off the rebar and the patient was brought to the emergency department. On arrival patient was conscious and hemodinamically stable. On physical examination a rebar of 1,5 meters long was seen stuck in the right hemiscrotum penetrating from the anterior aspect near the raphe, directing towards the pubic bone and exiting from the suprapubic region by skimming the superior ramus of the pubic bone from above, following a relatively superficial route.

Address for Correspondence / Yazışma Adresi: Ramazan Karabulut, MD Gezegen Sokak No:1/10 06670 GOP Çankaya, Ankara, Turkey Tel: +90 312 2026210 Fax: +90 3122026212 E-mail: karabulutr@yahoo.com

(CTelif Hakkı 2016 Gazi Üniversitesi Tıp Fakültesi - Makale metnine http://medicaljournal.gazi.edu.tr/ web adresinden ulaşılabilir. 
The bar was lying towards the left breast and had caused abrasions on the skin (Fig. 1). There was no significant bleeding. On an initial quick examination, penis, urethra and rectum appeared intact. Patient urinated easily without hematuria. Patient was taken to the operation room directly to identify any associated injury to the nearby structures and to remove the rebar. After removing the rebar, a defect about $2 \mathrm{~cm}$ in diameter and $15 \mathrm{~cm}$ long was detected. The index finger could be inserted from the both ends easily. As the penetration was superficial and above the pubis and exited through the abdominal skin the urethra, bladder, rectum or other intraabdominal organs were unaffected. Right testis and tunica albuginea were uninjured, and vas deferens and the vessels were intact throughout the inguinal canal (Fig. 2). Urethral pathology was absent. Left scrotum and structures were not affected. After irrigation with saline, the wound was debrided and closed over a drain. The patient received anti-tetanus prophylaxis and antibiotics in the postoperative course. Postoperative course was uneventful. On the third postoperative day the drain was removed. The patient was seen to recover fully at the follow up one month later.

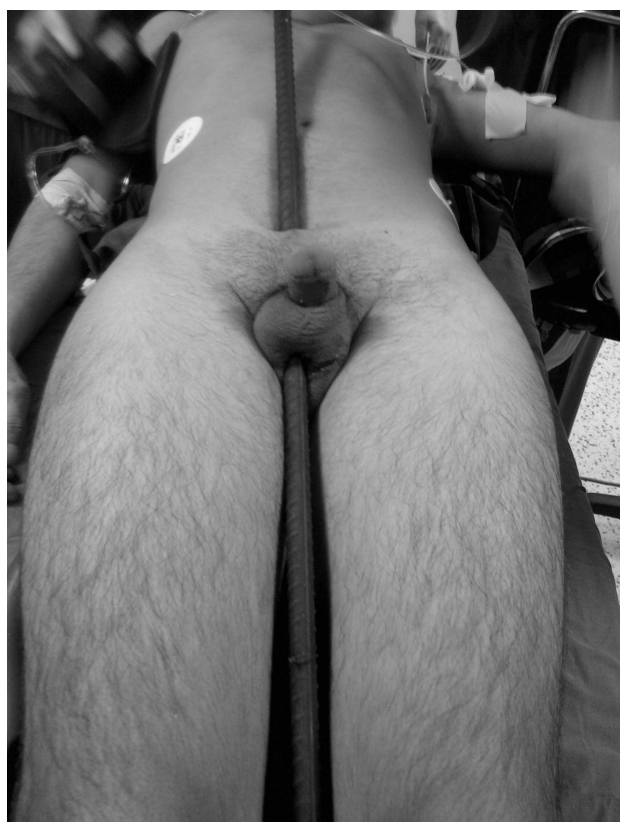

Figure 1. Scrotal penatratation by rebar

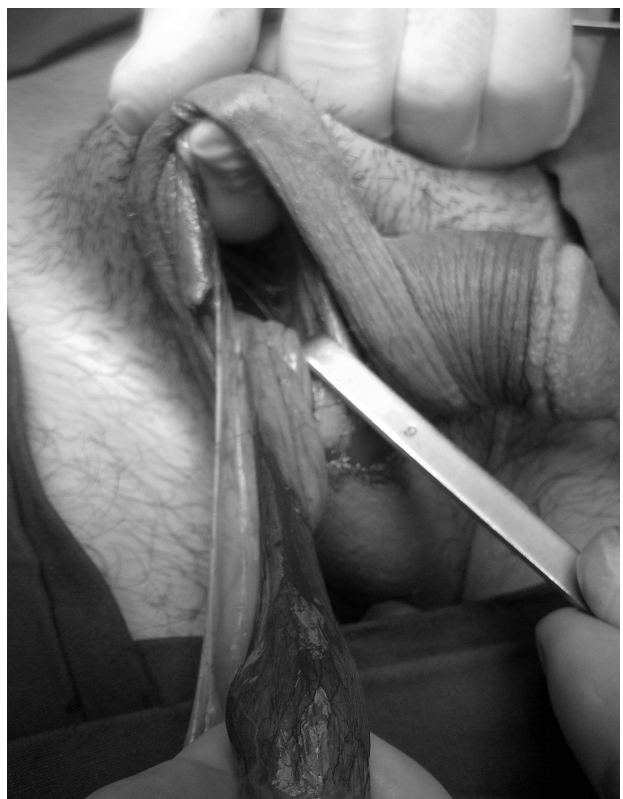

Figure 2. Scrotal expolaration of the rebar showing normal vas deferens and testis.

\section{DISCUSSION}

Penetrating scrotal trauma usually results with injury to immediate structures including testis, urethra, vas deferens and vessels or adjacent nongenital structures. Sometimes intraabdominal organs can also be affected(2). In a limited number of published scrotal trauma cases in the literature, associated organ trauma or injury to adjacent structures were usually present. Schwarz and Blair reported a case of a 15 years old male who had a scrotal trauma caused by a broom handle which entered from left scrotum with an exit point through the abdominal wall along with liver laceration. They also published a 45 years old male with a scrotal trauma resulting from broom handle which injured the dartos fascia but unharmed the testis (4). Dorairajan and colleagues performed laparotomy on a 20 yearold male due to stab injuries to his left chest, left thigh and scrotum. During scrotal exploration, they found that both of the vas deferences were transected (5). Ferlise and colleagues reported a trauma case caused by approximately a 1.2 meters long javelin throughout the left scrotum which did not cause an associated injury similar to the present case(3).

The characteristics of these cases are that they are most often caused by accidents or consequent to fights and are usually associated with concomitant life threatening injuries. In our case, the trauma was related to a preventable incident. If the construction area was closed down or the entrance of children were prohibited this trauma could be avoided.

In the patients with scrotal trauma, examination under general anesthesia should be performed to identify and repair the injured structures.

\section{Conflict of interest}

No conflict of interest was declared by the authors

\section{REFERENCES}

1. Pogorelić Z, Jurić I, Biočić M, Furlan D, Budimir D, Todorić J, Milunović KP. Management of testicular rupture after blunt trauma in children. Pediatr Surg Int 2011; 27:885-9.

2. Onen A, Oztürk H, Yayla M, Basuguy E, Gedik S. Genital trauma in children: classification and management. Urology 2005; 65: 98690.

3. Ferlise VJ, Haranto VH, Ankem MK, Barone JG. Management of penetrating scrotal injury. Pediatr Emerg Care 2002; 18:95-6.

4. Schwarz RJ, Blair GK. Trans-scrotal intra-abdominal injuries: two case reports. Can J Surg 1995; 38:374-6.

5. Dorairajan LN, Kumar S, Madhekar N. Bilateral transection of the vas deferens: an unusual trauma from a cross stab injury of the scrotum. Urol Int 2001; 66:169-70 